International Journal of Instruction e-ISSN: 1308-1470 • www.e-iji.net

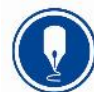

January $2022 \bullet$ Vol.15, No.1

p-ISSN: 1694-609X

pp. $259-276$

Article submission code:

20201116020935

Received: $16 / 11 / 2020$

Revision: 20/06/2021
Accepted: 15/07/2021

OnlineFirst: 17/10/2021

\title{
Development of Economic Learning Model Based on Pancasila Values
}

\section{Baseran Nor}

Doctoral student of Universitas Negeri Malang, Lecture in Universitas Lambung Mangkurat, Indonesia, baseran.nor.1704319@students.um.ac.id

\section{Ery Tri Djatmika}

Universitas Negeri Malang, Indonesia, ery.tri.fe@um.ac.id

\section{Sri Umi Mintarti Widjaja}

Universitas Negeri Malang, Indonesia, sri.umi.fe@um.ac.id

\section{Hari Wahyono}

Universitas Negeri Malang, Indonesia, hari.wahyono.fe@um.ac.id

Moral degradation is due to the lack of government attention in planning and supervising the learning process in education. This study aims to establish an economic learning model focused on Pancasila values in the Economic Education study program, Teacher Training and Education Faculty of Universitas Lambung Mangkurat, Banjarmasin. The research conducted is developmental research with the Dick \& Carey model. Researchers use tests, observations, interviews, and documentation for data collection. Data were analyzed using paired t-test statistics. A team of educational and content experts, educators, and small groups validated the learning model and its tools. In this study, the informants were 88 thirdsemester Economics education students who are programming Indonesian economy courses. The results showed that Pancasila economics was higher in the experimental class than in the control class. The results showed that Pancasila economics in the practical grade was higher than in the control class. According to the represented Pancasila's economic principles, the Game-Based Direct Instruction Learning paradigm effectively instilled students' knowledge, enthusiasm, and behavior. The inculcation of the Pancasila economic character such as honesty, teamwork, humanity, sense of family, cooperation, and fairness are required to restore the Indonesian nation's identity as mandated by law.

Keywords: development of economic learning model, value, direct instruction, games, Pancasila economic

\section{INTRODUCTION}

Our society currently faces alarming moral degradation situations, seen from the many criminal acts frequently reported on online and printed media. Those acts include

Citation: Nor, B., Djatmika, E. T., Widjaja, S. U. M., \& Wahyono, H. (2022). Development of economic learning model based on Pancasila values. International Journal of Instruction, 15(1), 259276. https://doi.org/10.29333/iji.2022.15115a 
stealing, murder, illegal drug use, promiscuity, and corruption. The results of studies conducted by Wylęgły (2019); Al Mamun et al. (2019); Prastyaningrum \& Supardi (2019); Hidayah \& Bowo (2018); Fitriyani et al. (2013) identify that most of the student's participant has ever associated in prostitution, accessed pornography, joined students fight, and they tend to have more extravagant spending to fulfill their secondary and tertiary need than their primary needs. Further, according to a report from World Economic Forum (WEE) yang released in The Global Competitiveness Report 20172018, Indonesia has a 13.8 index in corruption level that obstructs its business activities (Schwab \& Sala-i-Martin, 2017).

This moral degradation indicates the failure of Indonesia's education system to shape democratic and responsible society member who has faith and pious to The One Almighty God, with noble character and marvelous creativity, health, knowledge, and independence (Anonymous, 2003). Several issues emerge in the Educational field. One of them is learning processes that emphasize cognition rather than affection (Rohman, 2012). However, different approaches have been carried out to reduce this moral degradation, such as the economic solidarity movement against capitalism and individualism system (Ahmed, 2015; Kawano, 2018), morale financial education from Etzioni (1990), moral education meta-curriculum embedded in all aspect of school life (Hedayati et al., 2019), and Strengthening Character Education (Anonymous, 2017). These efforts illustrate the similar judgment of people to guide and shape good moral character. One of those attempts is carrying out character education that improves the future young generation's texture.

In addition, the government has also tried to reform the character through the integration of religious education in all courses, character reinforcement education program, anticorruption education, character-based parenting education program, and generation planning program. However, almost all of those programs have not involved universities. Meanwhile, universities have a significant role in shaping the young Indonesian generation, especially those that train prospective teachers, such as education-based universities. It is in line with the finding from research conducted by Januarti \& Hendrastomo (2017) that the pre-service teacher program in universities has to generate graduates with moral character by integrating the character education in the teacher ethic and profession course.

Character education cultivates excellent habits in life to attain high awareness, understanding, consideration, and commitment to implement virtue in their daily lives. Character is someone's natural feature in giving moral responses, materialized in excellent, honest, responsible, respecting others' behavior, as well as other positive character values (Hamid, 2017). Character education starts from the non-formal to the formal and informal education environment. One of the current massively developed character education is the implantation of Pancasila economic values. This education can complete through various means, such as the process of indoctrination, value clarification, example provision, and behavior habituation (Zulfatmi, 2016). Gunawan (2017) explains that character cultivation can be carried using some media, including the learning and teaching process, school culture habituation, extracurricular activities, and daily activities at home. The integrated character education into every course in higher 
education. As a result, character education is now the responsibility of all lecturers in all classes (Hidayati et al., 2020). The integration of character education in universities can be accomplished through lesson planning (syllabus, course unit, and learning material), learning implementation (initial, primary, and closing activities), and learning assessment (Nor, 2014).

Law of the Republic of Indonesia No. 12 the Year 2002 about University Education explains the higher education based on Pancasila, Constitution of State of Republic of Indonesia 1945, The Unitary State of the Republic of Indonesia, and Bhinneka Tunggal Ika. It confirms that the learnings in universities should be held based on Pancasila and the Constitution of the State of Republic of Indonesia 1945. In other words, those learnings have to contain the means to cultivate character or values of Pancasila and the Constitution of the State of Republic of Indonesia 1945 to the students. Therefore, the learning process has to design to accomplish national education goals. One of them is using a learning model capable of implanting economy Pancasila values and providing the learning material based on Pancasila and the Constitution of State of Republic of Indonesia 1945. Thus, this study aims to develop an economic learning model based on Pancasila values for Economy Education students of Teacher Training and Education Faculty of Universitas Lambung Mangkurat, Banjarmasin.

Pancasila was the ideology and philosophy of the Indonesian people (Fossati et al., 2020). Pancasila is used as a basis and guideline for the behavior of all Indonesian people. Pancasila consists of five principles that contain the noble values of the Indonesian people. Pancasila's economy was an economic system with dimensions of justice, equal rights, and management of natural resources used to benefit the community based on the principle of benefit (Jaelani, 2016). Although they had specificity, the values contained in Pancasila are universal and global. The difference only lies in the implementation process wherein the Pancasila economy each value was interrelated and inseparable from one another. The Pancasila economic system was known by many terms, including the populist economy and the creative economy. Although different, the core of the concept was the same: applying Pancasila values in economic behavior. The Pancasila principles, according to the Indonesian Government Translator Association (IPPI) (Anonymous, 2020); (Agussalim et al., 2021); and (Salampessy et al., 2018), were as follows: (1) Belief in the one and only God; (2) Just and civilized humanity; (3) The unity of Indonesia; (4) Democracy guided by the inner wisdom in the unanimity arising out of deliberations amongst representatives; and (5) Social justice for all of the people of Indonesian.

Excellent learning carries substantial effects on students. Those effects range from the transformation of students' knowledge of their daily behavior. The current learning advancement has highlighted character cultivation. One of the growing characters is the economy Pancasila character, which deliberates Indonesian society behavior in economy activities linear with Pancasila and Constitution of State of Republic of Indonesia 1945. A study carried out by Ainun N et al. (2018) invents an economic learning environment based on Pancasila, article 33 of Constitution of State of Republic of Indonesia 1945, and the realization of economic learning results that transform students' knowledge, behavior, and skills. 
Joyce et al. (2015) organize the learning model into four groups, namely information processing model (which emphasizes someone's creativity and skills on converting stimulus and data organization), social interaction model (which emphasizes the relationship between an individual with other individuals and individual with society), personal model (highlights the development of self-concept on the individual to create productive relationships with other people and their surrounding), and behavioral model (emphasizes on students' behavioral changes, so that it is consistent with their selfconcept). Therefore, this study develops a learning model that shapes students' character and economic behavior in line with Pancasila and the Constitution of the State of Republic of Indonesia 1945 on Economy Education students of Teacher Training and Education Faculty of Universitas Lambung Mangkurat. The developed learning model was classified as a behavior model. Direct instruction learning belongs to the behavioral learning model that accentuates behaviors and skills patterns to students. The instructor optimizes the reinforcement of students' behaviors that emerges during the learning process.

The direct instruction learning model can implant economic behavior following Pancasila values since it is equipped with strict instruction and control from the lecturer so that the learning reflects the established objectives. Besides, this model perceives all students can learn to escalate their academic and self-image; thereby, all teachers can be successful once they obtain complete and appropriate materials and controls during the learning (Steffen, 2016). It is following Joyce et al. (2011) that the direct learning model carries advantages, such as academic focus (robust students involvement), teacher direction and control (guide the task completion, emphasize the students' primary role in the instruction, minimize students' non-academic conversation), the great expectation on students development (realizing academic advancement and conducive behavior to enhance the education), time management system (maximize students learning time and promote the independence in accomplishing educational objectives) and relatively neutral atmosphere (learning environment that reinforces students active involvement and avoiding harmful practices). Pancasila-based economy behaviors are identic with someone's behavior in a social environment. Thus, the direct instruction learning model can exhibit and correlate with high social attitudes (Santyasa et al., 2019).

In contrast to other learning models, direct instruction learning tends to bring less significant effects. For instance, problem-based learning is more potent in improving students' mathematic literacy than the direct instruction learning model (Firdaus et al., 2017). Besides, the average students' social skills in social science education courses enhanced with the Creative Problem Solving (CPS) learning model than the Direct Instruction (DI) learning model (Nafisah et al., 2019). However, another research discovers no significant difference in learning model, method, and skills between students who learn using direct instruction and the discovery learning model (Munfa'ati et al., 2020).

Most of the time, the direct instruction learning model only implemented theoretical and practical courses, such as mathematics and physical education (Smith et al., 2015; Firdaus et al., 2017). Direct instruction regard as a model for teacher-centered learning that requires cognitive and skills aspects. However, this learning model is more effective 
for materials viewed as new by students and varies with other learning models. A study conducted by Sabri et al. (2020) confirms that the implementation of direct instruction learning incorporated with audio affects fifth-grade elementary students listening skills on folklore material. Additionally, research carried out by Risdianto et al. (2020) also reveals that ethno science-based direct instruction learning affects students' critical thinking skills.

This study combines direct instruction learning with games to create a more enjoyable process. The games also escalate students' active involvement in the learning process since it is experienced-based. Students' experiences are improved when the games equip with the lecturer's instruction (Westera, 2019). Besides, games also modify the teacher's role in enhancing students' learning motivation by providing more discussion periods and learning materials (Wang \& Khambari, 2020). In line with those findings, Irmansyah et al. (2020) report that modifying the traditional game" Gobak Sodor" shapes children's social skills. Therefore, the use of games facilitates the formation of students' skills and mild and fun learning.

In this study, the game utilization aims to create a planned and repeated cultivation of Pancasila values. The selected games customize to the material used in the learning process. The Pancasila value insertion is carried out by directly practicing the Pancasila economic value during the game. It is relevant to various studies' findings that effective moral or character cultivation obtain through constant learning, habituation, training, and simulation (Rohman, 2012; Witro et al., 2020; Martanti, 2020; Amri et al., 2020). Kusdarini et al. (2020) research also reveals that students attain different meaningful experiences from applying Pancasila values in society through the fieldwork learning model. The game learning model is considered entertaining and fun and emphasized students' active involvement during the learning process. Game is an entertainment alternative for both children and adults (Wulansari et al., 2016). The lecture selected the game-based direct instruction learning model to facilitate students learning Pancasila's economic values and practice the values independently or with the lecturer's guidance throughout the learning or outside the classroom.

The research hypothesis of the economic learning model based on Pancasila values through game-based direct instruction learning model can improve students' knowledge, enthusiasm, and economic behavior based on Pancasila values in daily life.

\section{METHOD}

This study uses a Dick and Carey development model consisting of 10 stages. Those stages involve 1) identify instructional goals, 2) conduct instructional analysis, 3) analyze learners and context, 4) write performance objectives, 5) develop assessment instrument, 6) develop instructional strategy, 7) develop and select instructional materials, 8) design and conduct a formative evaluation of instruction, 9) revise instruction, and 10) design and conduct summative evaluation (Dick et al., 2015). The product created from this research is learning model syntax, learning materials, and learning guidance.

This study uses a quasi-experimental design. Informants were group into two classes, namely the experimental class, where the learning process uses games-based direct 
instruction, while the control class uses conventional learning models. The material presented is teaching material that researchers have developed. The lecturer teaches the subject given a semester learning plan that contains the stages of the meeting and the learning material that will deliver unique material on the economy of Pancasila given in 8 sessions.

The paired t-test statistic and interview results with informants were used to measure the learning model's effectiveness. If the t-test $>\mathrm{t}$ table for $\mathrm{N}=39$ on the $95 \%$ significance is 2.028 and $\mathrm{N}=51$ on the $95 \%$ significance is 2.009 or the significance value of t-test < .05 , then it indicates a difference between the initial and after-treatment scores. The effectivity is presumed to be high if the initial average score is lower than the aftertreatment average score.

This study focused on the effectiveness of the game-based direct instruction learning model in cultivating the Pancasila economy values. In this study, the participants or informants were 88 Economic Education students of Teacher Training and Education Faculty of Universitas Lambung Mangkurat, taking the Indonesia Economic course in the third semester with the following details:

Table 1

Detail of research subjects

\begin{tabular}{|c|c|c|c|c|c|c|c|}
\hline \multirow{2}{*}{ No. } & \multirow{2}{*}{ Cluster } & \multirow{2}{*}{ Female } & \multirow{2}{*}{ Male } & \multicolumn{2}{|l|}{ Age } & \multirow{2}{*}{ Amount } & \multirow{2}{*}{ Class } \\
\hline & & & & $18-19$ & $20-22$ & & \\
\hline 1 & $\mathrm{X} 1$ & 38 & 13 & 8 & 43 & 51 & Control \\
\hline 2 & $\mathrm{X} 2$ & 23 & 14 & 5 & 32 & 37 & Experiment \\
\hline $\mathrm{Am}$ & & 61 & 27 & 13 & 75 & 88 & \\
\hline
\end{tabular}

The sample was determined randomly, where the experimental class (X2) learning used games-based direct instruction, while the control class (X1) used conventional learning models. Each teaching lecturer given the material on Pancasila Economics; assessment instruments developed by the researcher. Data collection techniques with the test, observations, interviews, and documentation. At the beginning of the lesson, the informant was given a written test related to the level of knowledge about Pancasila economics. Then at the last meeting, to see the effectiveness of the learning model, the lecturer did a post-test which consisted of the initial test questions plus several new questions.

The essay question is used to measure the knowledge of Pancasila Economy with the following instruction grid:

Table 2

Essay questionnaire

\begin{tabular}{llll}
\hline No. & Material & Indicator & Item \\
\hline 1 & $\begin{array}{l}\text { Different economic systems in the } \\
\text { world }\end{array}$ & $\begin{array}{l}\text { Explain the concept of liberalism, socialist, and } \\
\text { Pancasila economic systems }\end{array}$ & 2 \\
\hline 2 & Pancasila economic concepts & $\begin{array}{l}\text { The characteristic of the Pancasila economy that is } \\
\text { associated with its implementation }\end{array}$ & 2 \\
\hline 3 & Pancasila economic values & $\begin{array}{l}\text { The role of Pancasila values in daily life an economic } \\
\text { agents }\end{array}$ & 3 \\
\hline 4 & $\begin{array}{l}\text { The Implementation of Pancasila } \\
\text { Economics in Indonesia }\end{array}$ & $\begin{array}{l}\text { Constraints faced by the government and society in the } \\
\text { application of the Pancasila economy }\end{array}$ & 3 \\
\hline & Amount & & 10 \\
\hline
\end{tabular}


The questionnaire has used an instrument to measure the Pancasila economy of participants with the following questionnaire grids.

Table 3

Research questionnaires grilles

\begin{tabular}{llll}
\hline No. & Material & Indicator & Item \\
\hline 1 & Religious & Continually thankful to the One Almighty God and honesty in every time & 3 \\
\hline 2 & Teamwork & Participation in mutual assistance activities or social activities & 3 \\
\hline 3 & Humanity & Share and help each other and harm others & 3 \\
\hline 4 & Nationalism & Protect each other and promote fellow Indonesian people & 3 \\
\hline 5 & Justice & Equally fed the principle of fairness of distributions and justice of contribution & 3 \\
\hline 6 & Enthusiasm & The feeling of pleasure, involvement, interest, and attention & 8 \\
\hline 7 & Behavior & Rationality, morality, and lifestyle in daily life & 7 \\
\hline & Amount & & 30 \\
\hline
\end{tabular}

Researchers designed game-based learning wherein the learning process can instill Pancasila economic values as a chronic process that becomes student behavior in social life. In addition, the syntax development of a game-based direct instruction learning model was presented in Table 4.

Table 4

Syntax of developed learning model

\begin{tabular}{|c|c|c|c|c|}
\hline No. & Model Stages & Lecturer Activities & Students Activities & Source \\
\hline 1 & Orientation & $\begin{array}{l}\text { Explaining the learning objectives, } \\
\text { illustrate the relation between learning } \\
\text { content and students' experience, and } \\
\text { discuss the learning procedure. }\end{array}$ & $\begin{array}{l}\text { They are conducting together } \\
\text { prayer, submitting daily } \\
\text { attendance, and listening to the } \\
\text { competencies to obtained. }\end{array}$ & $\begin{array}{l}\text { (Putranta et al., } \\
\text { 2018; Joyce et } \\
\text { al., 2011) }\end{array}$ \\
\hline 2 & Presentation & $\begin{array}{l}\text { Transferring information on new } \\
\text { concepts or skills by demonstrating } \\
\text { and giving examples. }\end{array}$ & $\begin{array}{l}\text { They are carefully observing } \\
\text { the material presented orally } \\
\text { using other learning media. }\end{array}$ & $\begin{array}{l}\text { (Putranta et al., } \\
\text { 2018; Joyce et } \\
\text { al., 2011) }\end{array}$ \\
\hline 3 & $\begin{array}{l}\text { Structured } \\
\text { Practice }\end{array}$ & $\begin{array}{l}\text { They guide students through examples, } \\
\text { a variation of the game-based learning } \\
\text { model capable of implanting Pancasila } \\
\text { economy values. }\end{array}$ & $\begin{array}{l}\text { They are creating a group, } \\
\text { listening to the stages of the } \\
\text { learning model. }\end{array}$ & $\begin{array}{l}\text { (Putranta et al., } \\
\text { 2018; Joyce et } \\
\text { al., 2011) }\end{array}$ \\
\hline 4 & $\begin{array}{l}\text { Practices with } \\
\text { Lecturer's } \\
\text { Guidance }\end{array}$ & $\begin{array}{l}\text { They habituated students to practice } \\
\text { their understanding of Pancasila's } \\
\text { economic values in the learning steps, } \\
\text { responding to the appeared stimulus, } \\
\text { maintaining a conducive learning } \\
\text { environment. }\end{array}$ & $\begin{array}{l}\text { They are actively following the } \\
\text { learning activities by } \\
\text { discussing each stage of the } \\
\text { learning model. }\end{array}$ & $\begin{array}{l}\text { (Putranta et al., } \\
\text { 2018; Joyce et } \\
\text { al., 2011) }\end{array}$ \\
\hline 5 & $\begin{array}{l}\text { Independent } \\
\text { Practice }\end{array}$ & $\begin{array}{l}\text { They ask students to practice } \\
\text { Pancasila's economic behavior in their } \\
\text { daily activities in their family, college, } \\
\text { and society. }\end{array}$ & $\begin{array}{l}\text { They are practicing Pancasila } \\
\text { Economy behavior in their } \\
\text { daily activities. }\end{array}$ & $\begin{array}{l}\text { (Putranta et al., } \\
\text { 2018; Joyce et } \\
\text { al., 2011) }\end{array}$ \\
\hline
\end{tabular}

They used descriptive quantitative analysis to describe and analyze the Economic Learning Model's effectiveness based on Pancasila Values, which learned from the knowledge, enthusiasm, and behavior of the Pancasila value-based economy in daily life. The rules of decision-making were based on the interval classes below. 
Table 5

Program effective intervals

\begin{tabular}{lll}
\hline \multirow{2}{*}{ No } & \multicolumn{2}{l}{ Knowledge, enthusiasm, and behavior of the Pancasila economy } \\
\cline { 2 - 3 } & Interval & Category \\
\hline 1 & $50-59$ & Ineffective \\
\hline 2 & $60-69$ & Less effective \\
\hline 3 & $70-79$ & Effective \\
\hline 4 & $80-90$ & Very effective \\
\hline
\end{tabular}

Source: Adapted from Agussalim et al. (2021)

Decision:

1. The success of the learning model if $\geq 70$ of Pancasila economic knowledge in the effective category

2. The success of the learning mode if $\geq 70$ of enthusiasm are in the effective category

3. The success of the learning model if $\geq 70$ of Pancasila's economic behavior in the effective category.

\section{FINDINGS AND DISCUSSION}

During the research activities of 90 students, two people did not complete the entire learning model for no reason, so that they were excluded as participants. The number of participants was 88 people. After conducting data analysis activities with the help of the excel program on Pancasila economic knowledge, participants can identify as follows.

Table 6

Knowledge of Pancasila economics

\begin{tabular}{llllll}
\hline \multirow{2}{*}{ No } & \multirow{2}{*}{ Interval } & \multirow{2}{*}{ Category } & Frequency & & \multirow{2}{*}{ Percent } \\
\cline { 4 - 5 } & & & Experiment & Control & \\
\hline 1 & $\leq 50-59$ & Ineffective & 9 & 12 & 23.86 \\
\hline 2 & $60-69$ & Less effective & 7 & 21 & 31.82 \\
\hline 3 & $70-79$ & Effective & 16 & 17 & 37.50 \\
\hline 4 & $\geq 80$ & Very effective & 5 & 1 & 6.82 \\
\hline & Amount & & 37 & 51 & 100 \\
\hline
\end{tabular}

Based on table 6, students still get an average score below the minimum completeness criteria, especially the control class. That is because the learning model used has not been able to motivate students to learn. However, overall, the economic learning model developed increased students' knowledge of Pancasila economics based on the average value obtained $\geq 70$ of $44.32 \%$. 
Table 7

The enthusiasm of the economic model learning on Pancasila values

\begin{tabular}{llllll}
\hline \multirow{2}{*}{ No } & \multirow{2}{*}{ Interval } & \multirow{2}{*}{ Category } & Frequency & & \multirow{2}{*}{ Percent } \\
\cline { 4 - 5 } & & & Experiment & Control & \\
\hline 1 & $\leq 50-59$ & Ineffective & - & 5 & 5.68 \\
\hline 2 & $60-69$ & Less effective & - & 11 & 12.50 \\
\hline 3 & $70-79$ & Effective & 12 & 25 & 42.05 \\
\hline 4 & $\geq 80$ & Very effective & 25 & 10 & 39.77 \\
\hline & Amount & & 37 & 51 & 100 \\
\hline
\end{tabular}

Based on table 7, 16 students (18.18\%) in the control class feel less enthusiastic about the learning model. It is different from the experimental class, which is very excited about the game-based direct instruction learning model (100\%) because learning is more exciting and fun. However, student enthusiasm for learning Pancasila economics is very high because it is a new material following the Indonesian economy.

Table 8

Pancasila economic behaviour

\begin{tabular}{llllll}
\hline \multirow{2}{*}{ No } & \multirow{2}{*}{ Interval } & \multirow{2}{*}{ Category } & Frequency & \multirow{2}{*}{ Percent } \\
\cline { 4 - 5 } & & Experiment & Control & \\
\hline 1 & $\leq 50-59$ & Ineffective & 2 & 15 & 19.32 \\
\hline 2 & $60-69$ & Less effective & 3 & 18 & 23.86 \\
\hline 3 & $70-79$ & Effective & - & 11 & 12.50 \\
\hline 4 & $\geq 80$ & Very effective & 32 & 7 & 44.32 \\
\hline & Amount & & 37 & 51 & 100 \\
\hline
\end{tabular}

Based on the table above, it can conclude that the Pancasila economic learning model can grow and generate student behaviors that are following Pancasila economic values in social interactions during the learning process with a percentage of $56.82 \%$ in the effective category. Behaviour is very visible in students from the experimental class, most of whom have led to economic behaviors based on Pancasila values such as being honest, helping friends who have difficulties learning, teamwork, humanity, and being fair to others.

The results of the initial and final tests can see in the table below:

Table 9

The distribution of the results of pre-test and post-test

\begin{tabular}{llllllllllllll}
\hline & \multicolumn{3}{c}{ Experiment class } & \multicolumn{8}{c}{ Control class } \\
\hline \multicolumn{3}{c}{ Pre-test } & \multicolumn{3}{c}{ Post-test } & \multicolumn{3}{c}{ Pre-test } & \multicolumn{3}{c}{ Pos-test } \\
\hline & Male & Female Total & Male & Female Total & Male & Female Total & Male & Female Total \\
\hline Amount & 14 & 23 & 37 & 14 & 23 & 37 & 12 & 39 & 51 & 12 & 39 & 51 \\
\hline Average & 43.93 & 52.83 & 49.46 & 78.57 & 85.22 & 82.70 & 47.50 & 47.05 & 47.16 & 71.67 & 78.85 & 77.16 \\
\hline Minimum 25 & 25 & 25 & 50 & 65 & 50 & 30 & 30 & 30 & 50 & 40 & 40 \\
\hline Maximum65 & 90 & 90 & 90 & 100 & 100 & 70 & 70 & 70 & 95 & 100 & 100 \\
\hline
\end{tabular}

Based on the table above, it can conclude that the level of students' initial knowledge about Pancasila economics is still low, as seen from the average value obtained by each 
class (49.46 and 47.16). Based on interviews with several students, they have never received information about Pancasila economics before taking the Indonesian Economy course. There is an increase in student's knowledge about the economics of Pancasila after attending lectures on Indonesian economics. The average experimental class (82.70) $>$ control class (77.16) indicates that the use of game-based direct instruction learning models is more effective in increasing knowledge compared to using conventional learning models. Meanwhile, based on gender, women are more dominant in using the games-based direct instruction learning model than traditional learning models. Follow the results of research Chung \& Chang (2017); Khan et al. (2017), which states that gender causes significant differences in learning motivation using game-based learning.

T-test statistics used to measure the effectiveness of the developed learning model using the SPSS. This t-test requires critical analysis of normality test, in which the data classified to have a normal distribution if the value of sig. $>.05$ and have homogenous distribution if the significance value is $>.05$ (Siswandari, 2011). The results of that analysis shown in Table 9.

Table 10

Results of normality with Kolmogorov-Smirnov

\begin{tabular}{lll}
\hline \multirow{2}{*}{ Variabel } & Class & \\
\cline { 2 - 3 } & Experiment & Control \\
\hline Initial Test Score & .167 & .157 \\
\hline Final Test Score & .184 & .160 \\
\hline
\end{tabular}

The data presented in Table 10 show that each variable sig. $=(.167 ; .184)$ and $(.157$; .067 ) has values above .05 , indicating that the data are normally distributed. At the same time, ANOVA analysis was used to test the data homogeneity. The results of that homogeneity test presented in Table 11.

Table 11

Results of homogeneity test

\begin{tabular}{lll}
\hline \multirow{2}{*}{ Variable } & Class & \\
\cline { 2 - 3 } & Experiment & Control \\
\hline Initial Test Score & .502 & .732 \\
\hline Final Test Score & .067 & .952 \\
\hline
\end{tabular}

Table 11 demonstrates that the score for each analysed variable sig. $=(.502 ; .067)(.732$; $.721)>.05$; thus, the data obtained in this study have a similar variation. The fulfillment of the above classical required tests indicates that t-test analysis could be used in this study to reveal the effectivity of Pancasila values-based learning model implementation for Economy Education students of Teacher Training and Education Faculty of Universitas Lambung Mangkurat.

The developed learning model presumed to be effective if the initial and final scores have a higher value of $t_{\text {count }}$ than the $t_{\text {table }}$ value, with a confidence level of $95 \%$ and degree of freedom $(\mathrm{df})=(\mathrm{n}-1)=(37-1)=36$ is 2.028 and $\mathrm{df}=(51-1)=50$ is 2.009 . The results of the data analysis shown in Table 12. 
Table 12

Results of T-Test analysis

\begin{tabular}{llllll}
\hline Class & $\mathrm{N}$ & Average & T-test Score & df & sig. \\
\hline Experiment & 37 & -33.243 & -13.349 & 36 & 0.000 \\
\hline Control & 51 & -30.000 & -12.990 & 50 & 0.000 \\
\hline
\end{tabular}

According to Table 12, the value of $\mathrm{t}(36)=-13.349(13.349)$ and $\mathrm{t}(50)=-12.990$ $(12.990)$ are higher than the $t_{\text {table }}$ value of $(2.028 ; 2.009)$. Meanwhile, the significance is $.000<.05$. Therefore, it indicates a significant difference between the initial and final scores after students attended Pancasila values-based learning. Students' average experiment class score (33.243) higher than their average control class (30.000). It shows that the developed economic learning model has excellent effectiveness in improving students' knowledge of Pancasila economy values.

\section{DISCUSSION}

The study results stated that there were differences before and after students of the ULM Economic Education study program who took the Indonesian Economy course. The economic games learning model based on Pancasila values can increase students' knowledge of the Pancasila economy. The limited literature on Pancasila economics causes difficulties for both lecturers and students in the learning process. The development of teaching materials in this study facilitates students' understanding of the economy of Pancasila. The use of direct instruction-based games learning model and making it more accessible can make the learning process more exciting and enjoyable in transferring knowledge about the new Pancasila economy for students. Mastery of material about the basic economy of Pancasila for students to apply and practice it in everyday life and transmit it to people around them. The existence of an understanding of the Indonesian people about the Pancasila economy will make it easier for the government to implement an economic system that is by the identity of the Indonesian nation

The economic learning model based on Pancasila values can increase student enthusiasm in the Pancasila economic learning process. Learning would be more meaningful if it followed enthusiastically. Enthusiasm appears when knowledge is engaging, fun, and following the learner's learning style. Utilizing the game-based direct instruction learning model in the Indonesian Economy course has advanced it into more meaningful and enjoyable learning. It is exhibited from students' enthusiasm and motivation during the Pancasila economy learning, as proven from their high attendance percentage. Even the students who have known to be passive become more active during the learning process. They even offer themselves to be part of the game by being a jury, supervisor, question reader, and timekeeper. They, who initially were ignorant during the learning, have become more excited. They even admitted that they missed that learning. Thus, students need a not stiff, more relaxed, but severe education that provides verbal and non-verbal rewards from the lecturers. That learning erases the distance between the lecturers and students and their fear of a 'killer' lecturer. Like research by Zhang (2014), when students perceive their teachers as enthusiastic and energetic, they are more likely to be intrinsically motivated to learn and engage 
behaviorally, cognitively, and emotionally. A learning process based on mutual need and affection facilitates students' material comprehension and learning objectives. According to Westera (2019), a learning model can change students to be more active within the learning process since it was based on experience.

Students' understanding will be maximal if lecturers' guidance follows the game model during learning. The results of this study are in line with other related tasks such as the ones that used direct instruction with support with helpful verbal guidance (Graaf et al., 2019); direct instruction is more feasible for some students with spectrum autism using audio devices (Frampton et al., 2020). Besides, the direct instruction learning model improves students learning results (Nh \& Winata, 2016), enhances material comprehension with stages learning of training, guidance, and feedbacks (Jazimah \& Nugroho, 2020); and effective to be used in writing course for auditory and visual students (Munfa'ati et al., 2020). Besides, learning model variation is linear with the results of research conducted by Martinez-Santos et al. (2020), that the game-based approach carries benefits for physical exercise learning. Meanwhile, online game media aids the students' conceptual and mathematic reasoning using TGT type cooperative learning (Rohmah \& Wahyudin, 2016). Thus, the game helps to accentuate effective time management behaviors and academic knowledge. Additionally, the game also offers opportunities for teachers to introduce behavioral-based research (Lastrapes, 2016). A business simulation game facilitates students' involvement and raises their learning (Buil et al., 2020).

The economic learning model based on Pancasila values can foster student economic behavior by Pancasila values. During the learning process, the lecturer always explains and shows examples of economic behaviors that are by the values of Pancasila so that students can easily understand and practice them. Although not all Pancasila economic behavior has emerged, most of them have been shown by students based on observations. The values demonstrated by students who take the Indonesia Economy course are in line with the primary character values cultivated in the character reinforcement program (Hendarman et al., 2018). Those character values involve religion (love, peace, tolerance, respecting the religious and faith differences, strong determination, confidence, cooperation between religious believers, anti-violence and bullying, friendship, sincerity, do not force his opinion, and protect the vulnerable), nationalist (appreciate national cultures, maintain the country's culture, willing to sacrifice, excellent, has a lot of achievements, love their country, preserve the environment, law-abiding, discipline, respect the different culture, race, and religion), independent (hard worker, firm, professional, creative, brave, and lifelong learner), cooperation (appreciative, cooperative, inclusive, committed to the joint decision, deliberated consensus, solidarity, empathy, anti-discriminative, anti-violence, and volunteerism), and integrity (honesty, love truth, loyal, morally committed, anticorruption, fairness, responsible, exemplary, and respecting others, primarily those with a disability).

The students might have possessed those values from their local cultures or wisdom cultivated since their early education (Istiqomah \& Setyobudihono, 2014; Damayanti et 
al., 2020). However, those values only started to re-emerge after they attended this Pancasila values-based learning model. Those values were expected to be possessed by the global economic agents, primarily in Indonesia. Once that is achieved, the economy practitioners will always consider other people in carrying out every economic activity. In other words, they will not bring harm to others while gaining profits. This condition is linear with the current world economic development, hindered by the rampant capitalist or liberalist economy. A various movement against that capitalism ideology have appeared, such as the movement of Economy Social Solidarity (ESS) invented by Red Intercontinental de Promocin de la Economia Social Solidaria (RIPESS) that develops economy based on values and ethics, instilling democracy, pluralism, equality, fairness, mutualism, inclusivity, and creativity (Designing Regenerative Cultures, 2016). According to Kawano (2018), a solidarity economy is a global movement that establishes a sustainable and unbiased economy. This movement tries to transform the dominant capitalist and other authoritarian systems into a system that focuses on placing humans and the planet as the center to ensure society's basic needs.

\section{CONCLUSIONS}

Character education is required to reconstruct Indonesia's society characteristics, which have been irrelevant to Indonesia's identities, such as friendly, religious, familiarity, helpful, and uphold justice. As one of the institutions with a significant role in character education, universities must cultivate Pancasila's values-based economy characters. The implementation of game-based direct instruction learning effectively implanted Pancasila's economic values through consistent, repeated, and designed processes.

All learning instruments designated by researchers have been validated by experts on education and materials, practitioners, as well as a small group. Those instruments have categorized as excellent that do not require revision. The t-test statistic data obtained on students' initial and final scores from Pancasila values-based economy learning has fulfilled normality and homogeneity. The results of paired t-test analyses reveal a significant difference between the students' initial and final scores. The students' average final scores are higher than the average initial scores. Therefore, the developed economic learning model is highly effective in improving students' Pancasila economy values knowledge. Besides, students' enthusiasm and behavior presented during the learning process are following Pancasila's economic values.

This study's results bolster the character reinforcement program to improve and cultivate Pancasila's economic character values informal education. However, comparative research on other study programs with similar Pancasila economic interests and characteristics is required. Besides, an additional participant in the study will make the study results more accurate and generalize as essential characters. The courses related to the Pancasila economy have to place as compulsory introductory courses for every educational level. Everyone has a significant role in cultivating the Pancasila economy character toward Indonesia's young generation to restore Indonesia's identity in the future. 


\section{REFERENCES}

Agussalim, Widjaja, S. U. M., Haryono, A., \& Wahyono, H. (2021). Pancasila Economic Character Literacy Program for High School Students. International Journal of Instruction, 14(1), 235-252.

Ahmed, P. O. (2015). What does 'solidarity economy' mean? Contours and feasibility of a theoretical and political project. Business Ethics: A European Review, 24(4), 425435. https://doi.org/10.1111/beer.12063

Ainun N, M. T., Witjaksono, M., \& Wahyono, H. (2018). Pengembangan Skenario Pembelajaran Ekonomi Pancasila Berbasis Proyek melalui Metode Experiential Learning. Jurnal Pendidikan, 3(8), 1019-1022.

Al Mamun, M. A., Arafat, S. M. Y., Ambiatunnahar, Mst., \& Griffiths, M. D. (2019). Attitudes and Risk Factors of Pornography Consumption Among Bangladeshi University Students: An Exploratory Study. International Journal of Mental Health and Addiction, 17, 323-335. https://doi.org/10.1007/s11469-018-0021-7

Amri, F., Djatmika, E. T., Wahyono, H., \& Widjaja, S. U. M. (2020). The Effect of Using Simulation on Developing Students' Character Education in Learning Economics. International Journal of Instruction, 13(4), 375-392. https://doi.org/10.29333/iji.2020.13424a

Anonymous. (2003). Undang-Undang Republik Indonesia Nomor 20 Tahun 2003 tentang Sistem Pendidikan Nasional. www.hukumonline.com

Anonymous. (2017). Presidential Regulation of the Republic of Indonesia Number 87 of 2017 concerning Strengthening Character Education (PPK). www.hukumonline.com

Anonymous. (2020, May 31). 7 Cara Menyebut Isi Pancasila dalam Bahasa Inggris, Mana Pilihanmu? https://www.kalderanews.com/2020/05/7-cara-menyebut-isipancasila-dalam-bahasa-inggris-mana-pilihanmu/

Buil, I., Catalán, S., \& Martínez, E. (2020). Engagement in business simulation games: A self-system model of motivational development. British Journal of Educational Technology, 51(1), 297-311. https://doi.org/10.1111/bjet.12762

Chung, L.-Y., \& Chang, R.-C. (2017). The Effect of Gender on Motivation and Student Achievement in Digital Game-based Learning: A Case Study of a Contented-Based Classroom. EURASIA Journal of Mathematics Science and Technology Education, 13(6), 2309-2327. https://doi.org/10.12973/eurasia.2017.01227a

Damayanti, Widjaja, S. U. M., \& Hermawan, A. (2020). Moralitas Ekonomi dalam Perspektif Budaya pada Mahasiswa. Jurnal Pendidikan, 5(2), 153-156.

Dick, W., Carey, L., \& Carey, J. O. (2015). The Systematic Design of Instruction (Eighth). Pearson.

Etzioni, A. (1990). The Moral Dimension Toward a New Economics. 
Firdaus, F. M., Wahyudin, \& Herman, T. (2017). Improving primary students' mathematical literacy through problem-based learning and direct instruction. Academic Journal, 12(4), 212-219. https://doi.org/10.5897/ERR2016.3072

Fitriyani, N., Widodo, P. B., \& Fauziah, N. (2013). Hubungan Antara Konformitas dengan Perilaku Konsumtif pada Mahasiswa di Genuk Indah Semarang. Jurnal Psikologi Undip, 12(1), 1-14. https://doi.org/10.14710/jpu.12.1.1-14

Fossati, D., Aspinall, E., Muhtadi, B., \& Warburton, E. (2020). Ideological representation in clientelistic democracies: The Indonesian case. Electoral Studies, 63, 1-12. https://doi.org/10.1016/j.electstud.2019.102111

Frampton, S. E., Shillingsburg, M. A., \& Simeone, P. J. (2020). Feasibility and Preliminary Efficacy of Direct Instruction for Individuals With Autism Utilizing speechgenerating Devices. Behaviour Analysis in Practice, 13, 648-658. https://doi.org/10.1007/s40617-020-00412-3

Graaf, J. van der, Sande, E. van de, Gijsel, M., \& Segers, E. (2019). A combined approach to strengthen children's scientific thinking: Direct instruction on scientific reasoning and training of teacher's verbal support. International Journal of Science Education, 41(9), 1119-1138. https://doi.org/10.1080/09500693.2019.1594442

Gunawan, H. (2017). Pendidikan karakter: Konsep dan implementasi (Cetakan 4). Alfabeta.

Hamid, A. (2017). PENDIDIKAN KARAKTER BERBASIS PESANTREN: Pelajar dan Santri dalam ERA IT dan Cyber Culture. IMTIYAZ.

Hedayati, N., Kuusisto, E., Gholami, K., \& Tirri, K. (2019). Moral conflicts in Iranian secondary schools. Journal of Beliefs \& Value, 40(4), 464-476. https://doi.org/10.1080/13617672.2019.1618151

Hendarman, Saryono, D., Supriyono, \& Sunaryo. (2018). Konsep dan Pedoman Penguatan Pendidikan Karakter. Kementerian Pendidikan dan Kebudayaan Republik Indonesia.

Hidayah, N., \& Bowo, P. A. (2018). Pengaruh Uang Saku, Locus of Control, dan Lingkungan Teman Sebaya Terhadap Perilaku Konsumtif. Economic Education Analysis Journal, 7(3), 1025-1039. https://doi.org/10.15294/eeaj.v7i3.28337

Hidayati, N. A., Waluyo, H. J., Winarni, R., \& Suyitno. (2020). Exploring the Implementation of Local Wisdom-Based Character Education among Indonesian Higher Education Students. International Journal of Instruction, 13(2), 179-198. https://doi.org/10.29333/iji.2020.13213a

Irmansyah, J., Lumintuarso, R., Sugiyanto, FX., \& Sukoco, P. (2020). Children's Social Skills Through Traditional Sports Games in Primary Schools. Cakrawala Pendidikan, 39(1), 39-53. https://doi.org/10.21831/cp.v39i1.28210 
Istiqomah, E., \& Setyobudihono, S. (2014). The Cultural Value of Banjar Communities in South Kalimantan: Indigenous Study. Journal of Theory and Applied Psychology, 5(1), 1-6. http://dx.doi.org/10.26740/jptt.v5n1.p1-6

Jaelani, A. (2016). Pancasila Economic and the Challenges of Globalization and Free Market in Indonesia. MPRA Paper, 70279, 1-19.

Januarti, N. E., \& Hendrastomo, G. (2017). Implementsai Pendidikan Karakter Melalui Perkuliahan Etika dan Profesi Keguruan. Jurnal Pendidikan Karakter, 7(2), 240-254.

Jazimah, I., \& Nugroho, A. S. (2020). Model Direct Instruction untuk Mengembangkan Kemampan Penetapan Angka Kredit Guru sebagai Upaya Peningkatan Kompetensi Calon Guru Sejarah Profesional. KHAZANAH PENDIDIKAN: Jurnal Ilmiah Pendidikan, 14(1), 144-160.

Joyce, B., Marsha, W., \& Emily Calhoun. (2015). Models of Teaching: Vol. Ninth Edition. Pearson.

Joyce, B., Weil, M., \& Calhoun, E. (2011). Model of Teaching (Model-Model Pengajaran) (Eighth). Pustaka Pelajar.

Kawano, E. (2018). Solidarity Economy. Owl Grammar Press.

Khan, A., Ahmad, F. H., \& Malik, M. M. (2017). Use of digital game-based learning and gamification in secondary school science: The effect on student engagement, learning and gender difference. Education and Information Technologies, 22, $2767-$ 2804. https://doi.org/10.1007/s10639-017-9622-1

Kusdarini, E., Sunarso, S., \& Arpannudin, I. (2020). The Implementation of Pancasila Education Through Field Work Learning Model. Cakrawala Pendidikan, 39(2), 359369. https://doi.org/10.21831/cp.v39i2.31412

Lastrapes, R. E. (2016). Let Us Play: Using Research-Based Games to Facilitate Effective Instruction. Beyond Behavior, 25(3), 27-33. https://doi.org/10.1177/107429561602500305

Martanti, F. (2020). Integration of Aswaja Teaching: Concept of Strengthening Character Education in College. TAWASUT, 7(1). publikasiilmiah.unwahas.ac.id

Martinez-Santos, R., Founaud, M. P., Aracama, A., \& Oiarbide, A. (2020). Sport Teaching, Traditional Games, and Understanding in Physical Education: A Tale of Two Stories. Frontiers in Psychology, 11, 1-12. https://doi.org/10.3389/fpsyg.2020.581721

Munfa'ati, H., Mujiyanto, J., \& Suwandi, S. (2020). The Effect of Discovery Learning and Direct Instruction on EFL Learners with Different Learning Styles. English Education Journal, 10(3), 347-403. https://doi.org/10.15294/eej.v10i1.37131

Nafisah, D., Habsari, N. T., \& Riyani, M. (2019). Penerapan Model Creative Problem Solving (CPS) dan Direct Instruction (DI) Terhadap Keterampilan Sosial Mahasiswa pada Mata Kuliah Pendidikan Ilmu Sosial. Prosiding Seminar Nasional Peningkatan 
Mutu Pendidikan, 1(1), Article 1. http://publikasi.fkipunsam.org/index.php/semnas2019/article/view/7

Nh, M. I. S., \& Winata, H. (2016). Meningkatkan Hasil Belajar Siswa Melalui Penerapan Model Pembelajaran Direct Instruction. Jurnal Pendidikan Manajemen Perkantoran (JPManper), 1(1), 49-60. https://doi.org/10.17509/jpm.v1i1.3262

Nor, B. (2014). Integrasi Pendidikan Karakter dalam Pendidikan IPS di Perguruan Tinggi. Proceeding International Seminar on Character Education, 321-331. eprints.ulm.ac.id

Prastyaningrum, O., \& Supardi. (2019). The Role of National Character Building in History Learning as a Preventive Control of Violence Case Among Students. Advances in Social Science, Education and Humanities Research, 398, 1-8.

Putranta, H., Madjis M, R., Nur A., R., \& Mei S., N. (2018). Model Pembelajaran Kelompok Sistem Perilaku: Behavior System Group Learning Model. Universitas Negeri Yogyakarta.

Risdianto, E., Dinissjah, M. J., Nirwana, \& Kristiawan, M. (2020). The Effect of Ethno Science-Based Direct Instruction Learning Model in Physics Learning on Students' Critical Thinking Skill. Universal Journal of Educational Research, 8(2), 611-615. https://doi.org/10.13189/ujer.2020.080233

Rohmah, E. A., \& Wahyudin, -. (2016). Pengaruh Model Pembelajaran Kooperatif Tipe Teams Games Tournament (TGT) Berbantuan Media Game Online Terhadap Pemahaman Konsep dan Penalaran Matematis Siswa. EduHumaniora | Jurnal Pendidikan Dasar Kampus Cibiru, 8(2), 126-143. https://doi.org/10.17509/eh.v8i2.5135

Rohman, A. (2012). Pembiasaan Sebagai Basis Penanaman Nilai-Nilai Akhlak Remaja. Jurnal Nadwa, 6(1), 155-178.

Sabri, T., Soeharto, S., \& Afrizan, A. (2020). The Influence of Video Direct Instruction Model to Folklore Listening Skills in Elementary Schooll. Lingua Cultura, 14(1), Article 1. https://doi.org/10.21512/lc.v14i1.6339

Salampessy, Z., Triyuwono, I., Irianto, G., \& Hariadi, B. (2018). Pancasila Paradigm: Methodology of Wawasan Nusantara for Accounting of Pancasila. Australasian Accounting, Business and Finance Journal, 12(1), 102-117. https://doi.org/10.14453/aabfj.v12i1.7

Santyasa, I. W., Santyadiputra, G. S., \& Juniantari, M. (2019). Problem-based learning model versus direct instruction in achieving critical thinking ability viewed from students' social attitude in learning physics. Advances in Social Science, Education and Humanities Research, 335, 633-644.

Schwab, K., \& Sala-i-Martin, X. (2017). The Global Competitiveness Report 20172018. The World Economic Forum. 
Siswandari. (2011). Statistika Computer Based (2nd ed.). UNS Press.

Smith, L., Harvey, S., Savory, L., Fairclough, S., Kozub, S., \& Kerr, C. (2015). Physical activity levels and motivational responses of boys and girls: A comparison of direct instruction and tactical games models of games teaching in physical education. European Physical Education Review, 21(1), 93-113. https://doi.org/10.1177/1356336X14555293

Steffen, R. R. (2016). Reading Mastery Direct Instruction: A Literature Review on Comprehension and Fluency Growth. Culminating Projects in Teacher Development, 14. https://repository.stcloudstate.edu/ed_etds/14

Wang, D., \& Khambari, M. N. M. (2020). The Application of a Game-Based AR Learning Model in English Sentence Learning. Malaysian Online Journal of Educational Technology, 8(1), 63-71.

Westera, W. (2019). Why and How Serious Games Can Become Far More Effective: Accommodating Productive Learning Experiences, Learner Motivation, and the Monitoring of Learning Gains. Educational Technology \& Society, 22(1), 59-69.

Witro, D., Putri, B. A., Putri, L. A., \& Oviensy, V. (2020). Role of The Family in Formation of Children Characters Based Moral Knowing, Moral Feeling, and Moral Action. Tunas Cendekia: Jurnal Program Studi Pendidikan Islam Anak Usia Dini, 3(1), 97-103. https://doi.org/10.24256/tunas cendekia. v3i1.1202

Wulansari, S., Satoto, K. I., \& Martono, K. T. (2016). Perancangan Permainan "UangAndro" Sebagai Media Pembelajaran Pengenalan Mata Uang Rupiah pada Anak Berbasis Androit. Jurnal Teknologi dan Sistem Komputer, 4(2), 305-314.

Wylęgły, K. (2019). The Phenomenon of Prostitution Among Students. Journal of Education Culture and Society, 2, 55-63. https://doi.org/10.15503/jecs20192.55.63

Zhang, Q. (2014). Assessing the Effects of Instructor Enthusiasm on Classroom Engagement, Learning Goal Orientation, and Academic Self-Efficacy. Communication Teacher, 28(1), 44-56. https://doi.org/10.1080/17404622.2013.839047

Zulfatmi, Z. (2016). Internalisasi Nilai Melalui Student Centered Learning (SCL) Approach. Jurnal MUDARRISUNA, 6(2), 312-328. http://dx.doi.org/10.22373/jm.v6i2.1087 